\title{
EKSTRAKSI KNOWLEDGE TENTANG PENYEBARAN \#RATNAMILIKSIAPA PADA JEJARING SOSIAL (TWITTER) MENGGUNAKAN SOCIAL NETWORK ANAL YSIS (SNA)
}

\author{
Lyonly Tomasoa $^{1}$, Ade Iriani², Irwan Sembiring ${ }^{3}$ \\ 1,2,3 Fakultas Teknologi Informasi, Universitas Kristen Satya Wacana \\ Email: ${ }^{1}$ tomasoa29@gmail.com, ${ }^{2}$ ade.iriani@uksw.edu, ${ }^{3}$ irwan@uksw.edu
}

(Naskah masuk: 28 Januari 2019, diterima untuk diterbitkan: 25 April 2019)

\begin{abstract}
Abstrak
Memasuki tahun politik 2018-2019, Indonesia mengalami darurat hoax dimana isu-isu politik menyebar dengan sangat cepat terutama pada jejaring sosial yang merupakan wadah untuk menghubungkan setiap individu di seluruh dunia. Twitter sebagai salah satu jejaring sosial yang sering dipakai masyarakat Indonesia, menyebabkan isu-isu politik pun ikut terbawa dalam bentuk tagar (\#). Tagar \#RatnaMilikSiapa yang merupakan isu politik dari kasus hoax kebohongan penganiayaan RS di kota Bandung dijadikan sebagai tunggangan para pengguna twitter untuk membangun opini di masyarakat sehinga menjadikan hal tersebut sebagai hoax menjelang pemilihan Presiden 2019. Opini-opini dari setiap pengguna twitter tersebut telah menciptakan jaringan-jaringan komunikasi yang membahas tentang kasus politik penganiyayaan RS dengan tagar \#RatnaMilikSiapa . Penelitian ini bertujuan untuk mengidentifikasi aktivitas penyebaran tagar \#RatnaMilikSiapa dengan menggunakan metode Social Network Analyis (SNA) pada jejaring sosial twitter. Dalam penelitian ini, dilakukan identifikasi terhadap aktor utama dengan melakukan perhitungan sentralitas tingkatan atau degree Centrality (BC) sehingga dapat ditemukan aktor yang berpengaruh dalam terbentuknya kelompok-kelompok jaringan tweet \#RatnaMilikSiapa pada jejaring sosial twitter. Hasil dari penelitan ini adalah ditemukannya 3 aktor kunci (creator \& influencers) yang berasal dari 5 aktor utama penyebaran tweet \#RatnaMilikSiapa dengan mengidentifikasi adanya pertukaran berita yang dilakukan oleh para aktor utama dan didukung dengan perhitungan nilai sentralitas keperantaraan atau betweenness Centrality (BC). Kemudian juga ditemukannya 32 aktor boundary spanner yang merupakan dampak dari aktivitas pertukaran berita atau information exchange yang dilakukan oleh aktor kunci pada jaringan komunikasi dalam jejaring sosial twitter.
\end{abstract}

Kata kunci: Social Network Analysis, Jejaring Sosial, Pertukaran Berita, Aktor Kunci, Boundary Spanner.

\section{KNOWLEDGE EXTRACTION ABOUT SPREAD OF \#RATNAMILIKSIAPA IN SOCIAL MEDIA (TWITTER) USING SOCIAL NETWORK ANALYSIS (SNA)}

\begin{abstract}
Entering the political year of 2018-2019, Indonesia is facing a hoax crisis where political issues spread rapidly, especially on social media as a place for connecting people all over the world. Twitter as one of the popular social media, which is frequently used by the society of Indonesian, leads the political issues spread widely through the hashtag (\#). \#RatnaMilikSiapa which was a hoax case about RS persecution in Bandung turned as a way for Twitter users creating a judgment in the society so that that issue became a hoax approaching the Presidential Election of 2019. The opinions of Twitter users had created a communication network discussed RS persecution as a political issue with \#RatnaMilikSiapa. This research intends to identify the \#RatnaMilikSiapa deployment activity with the using of Social Network Analyis (SNA) method on Twitter. This research conducts the identification toward the main actors with degree Centrality $(B C)$ calculation until the actor who influenced the establishment of \#RatnaMilikSiapa tweet network groups on Twitter can be found. The results of this research are the researcher had found the three key actors (creator and influencers) which originated from 5 main actors who spread \#RatnaMilikSiapa tweet. The researcher identifies the information exchange which had been done by the main actors and the results supports by the value of betweenness Centrality (BC) calculation. Later, the researcher had found 32 actors of boundary spanner which was the impact of information exchange done by the key actors on the communication network of Twitter.
\end{abstract}

Keywords: Social Network Analysis, Social Media, Information Exchange, key actor, Boundary Spanner. 


\section{PENDAHULUAN}

Pada tahun 2018-2019, Indonesia memasuki tahun politik di mana pemilihan presiden (pilpres) pada april 2019 akan diikuti oleh dua bakal calon (balon) Presiden yaitu JKW dan PBW. Menjelang pilpres 2019, Indonesia mengalami darurat hoax yang ditimbulkan oleh oknum-oknum politik pendukung calon Presiden (capres).

Salah satu anggota tim pemenangan dari capres PBW yaitu RS pada bulan September 2018 telah membuat berita bahwa RS telah dianiaya oleh sekelompok orang di Bandara Husein Saatranegara, Bandung, Jawa Barat dan kemudian mengundang simpati dari elit tim pemenangan PBW, diantaranya FZ, AR dan PBW. Pada bulan Oktober 2018, RS mengaku telah merekayasa kabar penganiayaan dirinya di Bandung sehingga menjadikan kasus tersebut sebagai hoax yang diciptakan oleh RS (Erdianto, 2018; Rizqo, 2018). Namun dengan terungkapnya kebohongaan tersebut, muncul isu politik baru yang berpotensi sebagai hoax dimana RS dianggap oleh kubu PBW sebagai penyusup yang berasal dari kubu JKW untuk menghancurkan internal kubu tim pemenangan PBW (Supriyatna, 2018). Kabar bahwa RS merupakan penyusup direspon oleh pengguna jejaring sosial twitter dengan menuliskan tweet menggunakan tagar \#RatnaMilikSiapa sebagai bentuk opini keberpihakan RS dalam pemilihan Presiden 2019, sehingga hali ini bepotensi untuk menimbulkan hoax yang baru ditengah masyarakat. Indonesia yang menempati posisi 5 besar pengguna terbanyak jejaring sosial twitter (Wibowo \& Marwati, 2013), memungkinkan hoax dengan tagar \#RatnaMilikSiapa dapat menyebar dengan sangat mudah.

Twitter merupakan sebuah layanan microblogging yang sangat efektif untuk dijadikan sebagai tempat menjalin hubungan pertemanan dengan setiap orang yang ada di belahan dunia untuk dapat berkomunikasi, bertukar informasi berupa foto, video maupun tulisan dengan kecepatan sebanding dengan media masa konvensional (Madcoms, 2010; Situngkir, 2017). Pengguna twitter dapat menyebut pengguna twitter dengan mention@UserName dan juga menandai tweet dengan kata-kata kunci menggunakan hashtag atau tagar (\#) (Cossu dkk, 2015). Oleh karena itu, setiap pengguna twitter di Indonesia pun berpeluang menyebarkan berita, informasi, dan knowledge (pengetahuan) dengan tagar \#RatnaMilikSiapa dan membangkitkan relasi dengan aktor atau pengguna twitter lainnya.

Social Network Analysis (SNA) merupakan salah satu solusi yang tepat untuk menganalisa relasi yang terjadi dengan adanya tagar \#RatnaMilikSiapa pada jejaring sosial twitter. SNA merupakan sebuah metode yang berasal dari domain yang berbeda seperti teori grafik, sosiologi, fisika dan ilmu komputer untuk mempelajari tentang hubungan manusia dengan menggunakan teori graf, dengan pemanfaatan teori graf ini membuat SNA mampu memeriksa struktur dari hubungan sosial dalam suatu kelompok (Tsvetovat \& Kouznetsov, 2011; Saganowski, 2015).

Penelitan yang berjudul "A Social Network Analysis Of Twitter : Mapping the Digital Humanities Community" merupakan penelitan yang membahas tentang analisis dan identifikasi bidang dan para aktor didalam komunitas digital humanities yang masih berpegang pada batas-batas konsep disiplin akademis melalui jejaring sosial twitter. (Grandjean, 2016). Identifikasi yang dilakukan dengan visualisasi grafik to follow or be followed dan menyoroti pada hubungan struktur jaringan sangat membantu dalam melakukan clustering pada jaringan yang memiliki kesamaan karakteristik. Oleh karena itu, visualisasi yang dihasilkan pada penyebaran tweet dengan tagar \#RatnaMilikSiapa sangat penting untuk mengelompokan opini dan berita yang tersebar dalam jejaring sosial twitter.

Dalam penelitain ini, ukuran kedekatan aktor satu dengan aktor yang lain dalam analisis jaringan penyebaran tagar \#RatnaMilikSiapa pada jejaring sosial twitter adalah sentralitas (centrality). Sentralitas dibagi menjadi dua bagian yaitu Degree Centrality yang menunjukan popularitas aktor dalam sebuah jaringan sosial dan Betweenness Centrality (Sentralitas Keperantaraan) yang memperlihatkan posisi seorang aktor sebagai perantara (betweenness) dari hubungan aktor satu dengan aktor lain (Eriyanto, 2014).

Penelitian yang berjudul "Identification of Influencers in Social Media using Social Network Analysis (SNA)" yang merupakan penelitan yang membahas tentang identifikasi hoax influencers pada jejaring sosial menggunakan SNA dengan fokus pada pengukuran degree centrality, closeness centrality, dan betweenness centrality. Setiap pengukuran sentralitas dikombinasikan dengan pembobotan dan dimodelkan kedalam model herarki (Pudjajana dkk, 2018).

Adapun penelitan yang berjudul "Evaluating Influential Nodes In Social Networks by Local Centrality with a Coefficient" merupakan penelitian yang membahas masalah penyebaran influencer yang memiliki dampak positif dan negatif. Influencer apa pun di jejaring sosial dapat ditemukan menggunakan SNA. Perhitungan menggunakan Central Centrality with a Coefisien (CLC). Hasil perbandingan CLC dengan Degree Centrality, Betweenness Centrality, Closeness Centrality, K-Shell, dan Local Centrality menunjukkan bahwa CLC memiliki nilai efektif dalam menentukan influencer pada jejaring sosial (Zhao dkk, 2017).

Dengan adanya penelitian-penelitian SNA diatas, aktor penyebaran tweet dengan tagar \#RatnaMilikSiapa dapat diidentifikasi dengan melakukan perhitungan DC dan BC pada metode 
SNA yang merupakan salah satu tools atau enabler dari knowledge management (KM). KM merupakan pendekatan transdisipliner untuk meningkatkan pembelajaran dengan memaksimalkan penggunaan knowledge. Hal ini melibatkan implementasi dan penijauan aktivitas, proses sosial, dan teknologi untuk menciptakan (create), berbagi (sharing), menerapkan atau menggunakan knowledge.

Tujuan dari penelitian ini adalah untuk mengekstrasi knowledge yang terdapat didalam hubungan yang terjadi antar pengguna twitter sehingga dapat dilihat respon masyarakat terhadap adanya potensi hoax yang ditimbulkan dengan munculnya tagar \#RatnaMilikSiapa pada jejaring sosial twitter. Ekstraksi hanya difokuskan pada proses penyebaran dan pertukaran informasi atau berita yang dilakukan dengan metode Social Network Analysis (SNA). Pertukaran informasi (information exchange) merupakan bagian dari knowledge sharing yang adalah karakter penting dari knowledge management (Xianjin, 1994). Tidak mungkin untuk mewujudkan information exchange dilakukan oleh seorang individu dengan tidak adanya knowledge sharing (Yuan \& Jianbin, 2010). Salah satu dampak dari aktivitas pertukaran informasi adalah dengan adanya Boundary Spanner (BS) atau aktor-aktor yang berhubungan dua arah dengan lebih dari satu kelompok jaringan komunikasi yang diciptakan. (Committee Mb-007, 2005).

Dengan melakukan ekstraksi knowledge, alur penyebaran sebuah informasi dapat divisualisasikan dengan tujuan untuk melihat aktivitas pertukaran informasi, siapa pembuat informasi (creator), aktor penyebaran informasi (influencers), dan dampak yang di timbulkan terhadap aktor-aktor lain yang merupakan pengikut (followers) para aktor utama tweet \#RatnaMilikSiapa yang ditandai dengan adanya aktor Boundary Spanner (BS).

\section{METODE}

Penelitan ini menggunakan data tweet dengan tagar \#RatnaMilikSiapa pada jejaring sosial twitter sebagai dataset. Dataset tersebut akan diolah dan digunakan untuk aktivitas ekstraksi knowledge pada jejaring sosial twitter dengan menggunakan SNA. Adapun langkah pengumpulan dan pengolahan data yaitu :

- Menentukan tagar yang akang dijadikan patokan pengumpulan data di jejaring sosial twitter.

- Mengumpulkan data tweet yang menggunakan tagar \#RatnaMilikSiapa

- Normalisasi data dengan membuat hubungan antar aktor tweet berdasarkan retweet, reply, dan mention yang kemudian diolah dan dijadikan kedalam graf SNA

- Penerapan Sentralitas Tingkatan (degree centrality) untuk menentukan aktor utama penyebaran berita yang kemudian dilanjutkan dengan melakukan ekstraksi knowledge untuk melihat penyebaran dan pertukaran informasi antar aktor.

- Penerapan Sentralitas Keperantaraan (bettweenness centrality) untuk menentukan key actor dan boundary spanner dari hubungan keterkaitan antar jaringan yang dibangkitkan oleh aktor utama.

\section{HASIL DAN PEMBAHASAN}

Penelitian ini mengunakan data dari jejaring sosial twitter yang diambil dari tanggal 3-12 Oktober 2018 yang kemudian dijadikan sebagai dataset. Data yang kumpulkan berupa akun, tweet, retweet, mention, reply, serta tanggal dan waktu yang menggunakan tanda pagar (tagar) \#RatnaMilikSiapa. Akun dari pembuat status akan menjadi node dan setiap tweet, retweet, mention, dan reply akan menjadi relasi dari setiap node.

Penelitan ini berfokus pada aktivitas penyebaran \#RatnaMilikSiapa dimana relasi yang terjadi menjadi kunci utama dalam penyebaran dan pertukaran berita di jejaring sosial twitter. Tagar \#RatnaMilikSiapa yang diteliti merupakan berita yang muncul akibat dari dampak kebohongan RS mengenai penganiayaan terhadap dirinya di kota Bandung yang kemudian diakui sebagai sebuah kebohongan. Penyebaran tweet \#RatnaMilikSiapa dapat dilihat seperti pada Gambar 1.

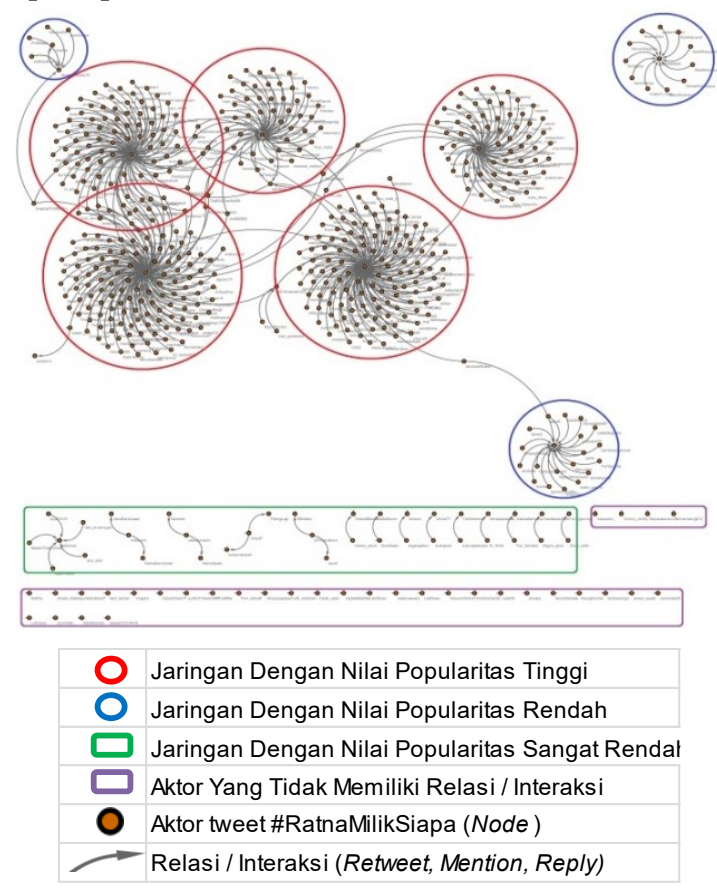

Gambar 1. Relasi Penyebaran \#RatnaMilikSiapa

Gambar 1 merupakan visualisasi dari relasi penyebaran tweet yang menggunakan tagar \#RatnaMilikSiapa yang diposting sebanyak 649 kali dan terdiri dari tweet, reetwet, mention, dan reply. Pada gambar tersebut, dapat dilihat adanya pola-pola penyebaran yang membentuk kelompok-kelompok jaringan komunikasi antar aktor pengguna twitter. 


\subsection{Popularitas Aktor}

Dalam jaringan komunikasi, terdapat aktoraktor yang dianggap sebagai aktor utama yang memiliki popularitas tertinggi dalam penyebaran berita. Aktor-aktor tersebut berperan penting dalam menciptakan kelompok-kelompok jaringan yang terdapat didalam relasi penyebaran \#RatnaMilikSiapa. Popularitas aktor dapat dilihat dengan analisa degree centrality (DC) pada jaringan relasi penyebaran \#RatnaMilikSiapa.

Tabel 1. Degree Centrality

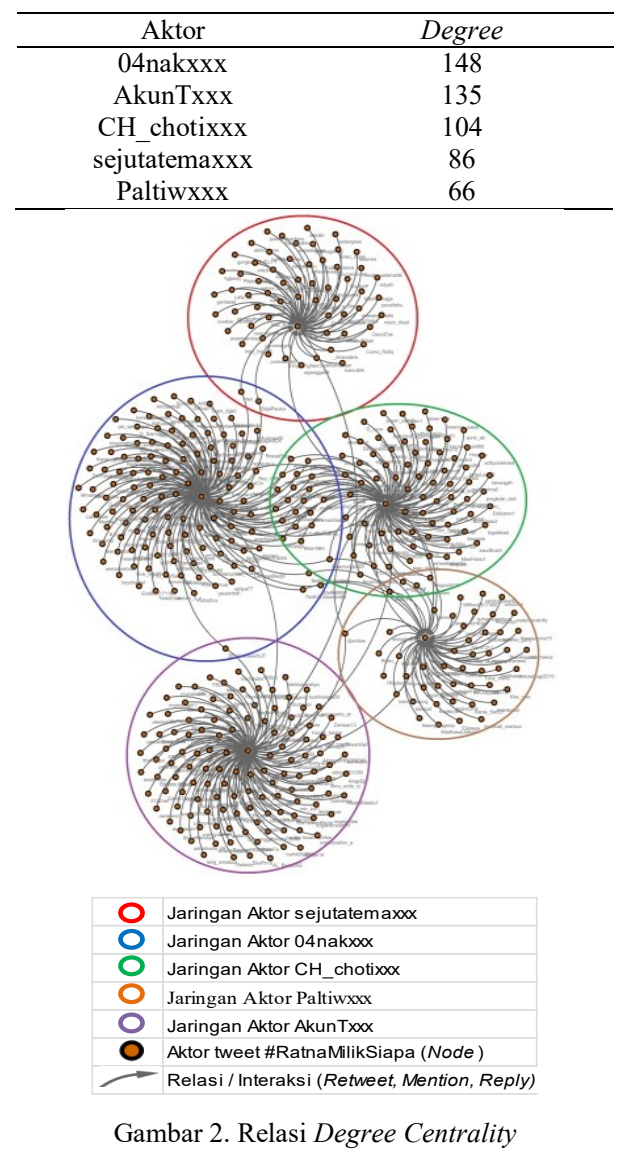

Tabel 1 dan Gambar 2 merupakan hasil dan visualisasi dari analisa degree centrality yang memperlihatkan popularitas aktor penyebaran \#RatnaMilikSiapa. Didalam tabel terdapat aktoraktor dengan popularitas tinggi antara lain : 04nakxxx, AkunTxxx, CH_chotixxx, sejutatemaxxx, Paltiwxxx. Aktor-aktor tersebut yang dijadikan sebagai aktor utama penyebaran tweet dengan tagar \#RatnaMilikSiapa.

\subsection{Ekstraksi Knowledge}

Ekstraksi terhadap Knowledge yang terdapat didalam relasi penyebaran \#RatnaMilikSiapa dalam jejaring sosial twitter hanya difokuskan pada informasi yang disebarkan oleh para aktor utama. Hal ini dilakukan dengan mengidentifikasi topik-topik berita yang terdapat didalam tweet yang diposting oleh para aktor tersebut untuk mengetahui reaksi para aktor utama terhadap \#RatnaMilikSiapa. Topik-topik yang disebarkan antara lain:

- 04nakxxx

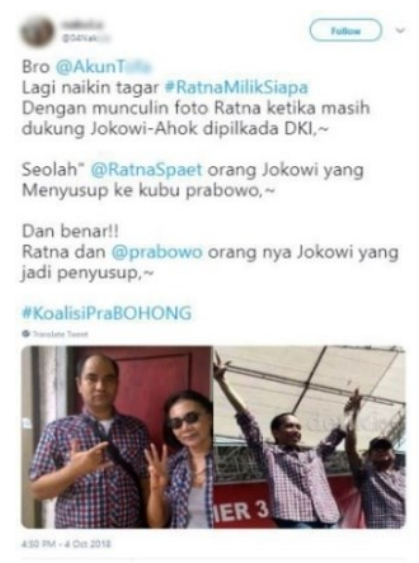

Gambar 3. Tweet 1 Postingan 04nakxxx

Gambar 3 memperlihatkan tweet yang dibuat oleh 04nakxxx dengan memberitahu bahwa aktor AkunTxxx sedang membuat tagar \#RatnaMilikSiapa yang didalamnya juga terdapat foto RS saat masa Pemilihan Kepala Daerah (Pilkada) Jakarta. Terlihat bahwa RS menggunakan baju kotak-kotak yang identik dengan JKW. Tweet ini dimuat pada tanggal 2018-10-04 23:50:21 UTC.

\section{- $\quad$ AkunTxxx}

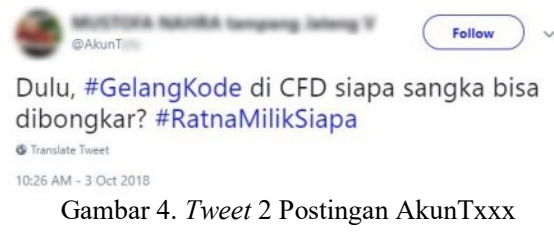

Gambar 4 merupakan tweet yang dibuat oleh AkunTxxx dengan membuat pertanyaan yang disertakan dengan \#RatnaMilikSiapa. Tweet ini dimuat pada tanggal 2018-10-03 17:26:02 UTC.

\section{- $\quad \mathrm{CH}$ chotixxx}

Gambar 5 merupakan tweet yang dibuat oleh CH_chotixxx yang berisikan sebuah pernyataan bahwa pada pilkada Jakarta, JKW didukung oleh PBW begitu pula RS Sebagai pendukung PBW pun ikut mendukung JKW saat itu. Pada tweet ini CH_chotixxx pun bertanya kepada AkunTxxx "mengapa bertanya dengan tagar \#RatnaMilikSiapa". Dalam postingan tersebut $\mathrm{CH}$ _chotixxx juga memasukan foto yang berisikan tweet AkunTxxx yang berupa pertanyaan dengan tagar \#RatnaMilikSiapa yang disertakan dengan foto RS menggunakan baju kotak-kotak tanda pendukung JKW. Tweet ini dimuat pada tanggal 2018-10-05 03:04:13 UTC. 

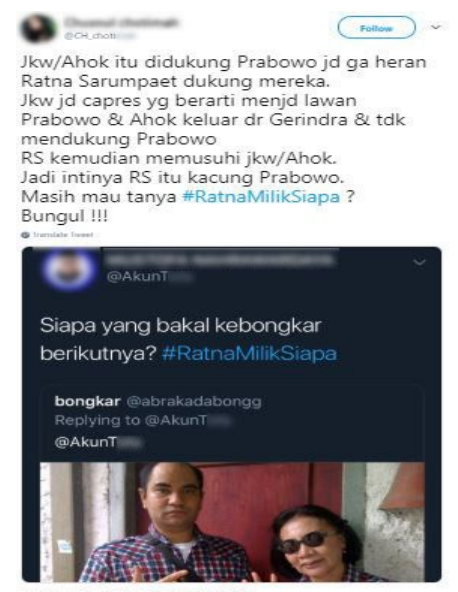

Gambar 5. Tweet 3 Postingan CH_chotixxx

- $\quad$ Sejutatemaxxx

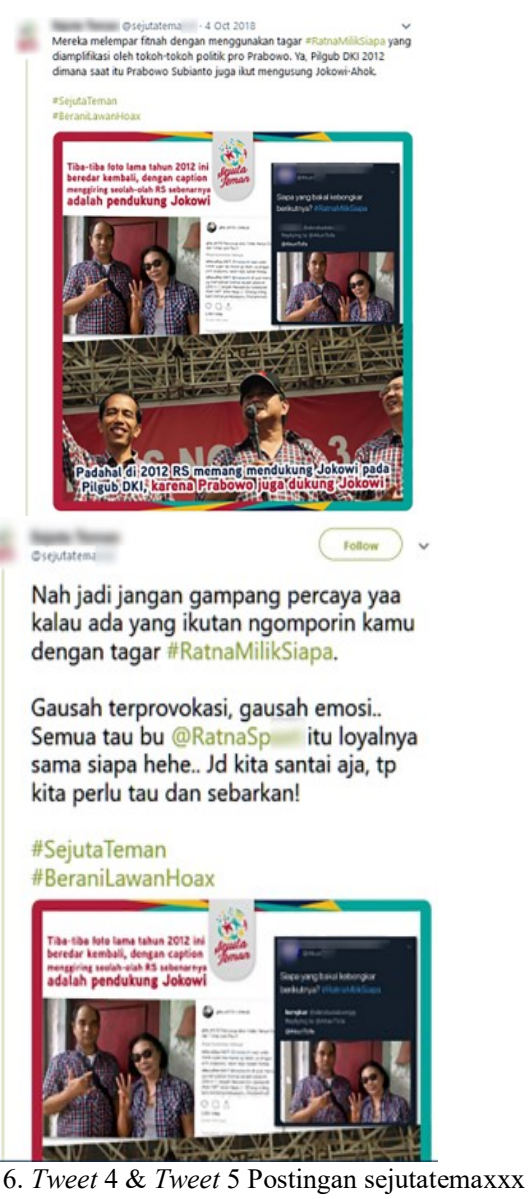

Gambar 6. Tweet 4 \& Tweet 5 Postingan sejutatemaxxx

Gambar 6 merupakan dua postingan dari sejutatemaxxx yang merupakan sebuah penyanggahan terhadap berita yang dibuat AkunTxxx yang menganggap kubu PBW melempar fitnah dengan menggunakan tagar \#RatnaMilikSiapa. Didalam tweet tersebut, sejutatemaxxx mengajak para pengguna twitter untuk tidak gampang percaya dengan opini yang dibangun menggunakan tagar \#RatnaMilikSiapa. Tweet ini masing-masin dimuat pada tanggal 2018-10-04 09:51:43 UTC dan 201810-04 09:54:03 UTC.

- Paltiwxxx

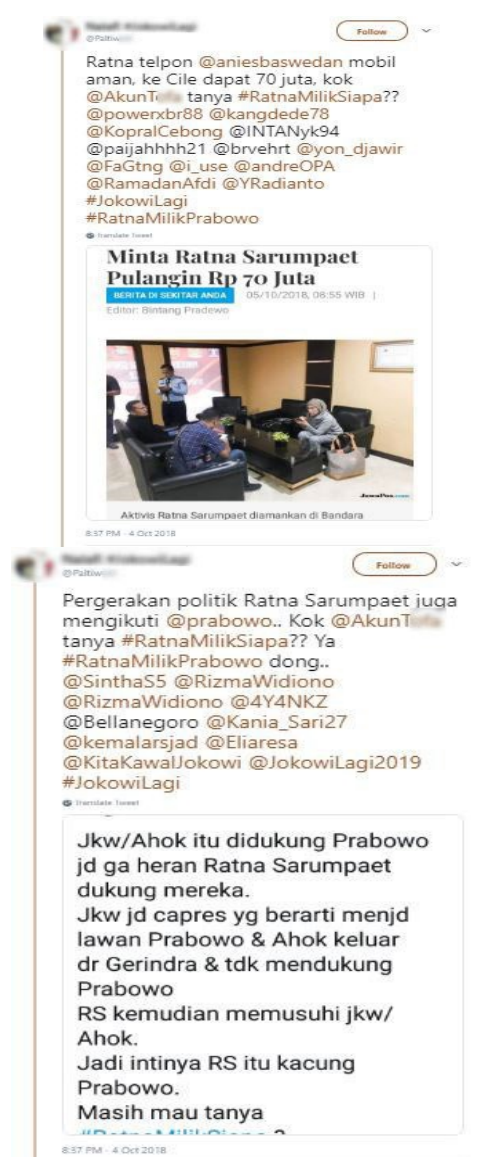

Gambar 7. Tweet 6 \& Tweet 7 Postiingan Paltiwxxx

Gambar 7 merupakan tweet yang dibuat oleh Paltiwxxx yang berisikan tentang berita rencana kepergian RS ke Cile dan juga sebuah pernyataan tentang pergerakan politik RS yang mengikuti PBW. Kedua postingan tersebut merupakan penyanggahan terhadap AkunTxxx yang bertanya menggunakan tagar \#RatnaMilikSiapa. Tweet ini dimuat masingmasing pada tanggal 2018-10-05 03:37:34 UTC dan 2018-10-05 03:37:37 UTC.

Setelah mengidentifikasi setiap tweet yang dibuat oleh para aktor utama yang merupakan berita atau informasi yang tersebar di dalam SNA \#RatnaMilikSiapa, informasi-informasi tersebut kemudian dibuat dalam tabel seperti pada tabel 2 .

Tabel 2 merupakan hasil dari identifikasi berita yang yang disebarkan oleh para aktor utama tweet \#RatnaMilikSiapa. Tabel tersebut menunjukan adanya keberpihakan para aktor utama dimana tweet yang dibuat oleh aktor AkunTxxx dibantah oleh 4 aktor utama lainnya dengan memunculkan faktafakta terbaru. 
682 Jurnal Teknologi Informasi dan Ilmu Komputer (JTIIK), Vol. 6, No. 6, Desember, hlm. 677-686

Tabel 2. Tabel Keterangan Tweet

\begin{tabular}{ccc}
\hline Aktor & Tweet & Keterangan Informasi \\
\hline 04nakxxx & Tweet 1 & Pemberitahuan Tagar \\
AkunTxxx & Tweet 2 & Membuat Tagar \\
CH_chotixxx & Tweet 3 & Penyanggahan Tagar \\
Sejutatemaxxx & Tweet 4 & Penyanggahan Tagar \\
Sejutatemaxxx & Tweet 5 & Penyanggahan Tagar \\
Paltiwxxx & Tweet 6 & Penyanggahan Tagar \\
Paltiwxxx & Tweet 7 & Penyanggahan Tagar \\
\hline
\end{tabular}

\subsubsection{Identifikasi Pertukaran Informasi}

Pertukaran informasi sangat penting dalam sebuah jaringan sosial. Didalam penelitian ini, informasi yang dimiliki oleh setiap aktor utama mengalami pertukaran seperti yang digambarkan pada gambar 8 .

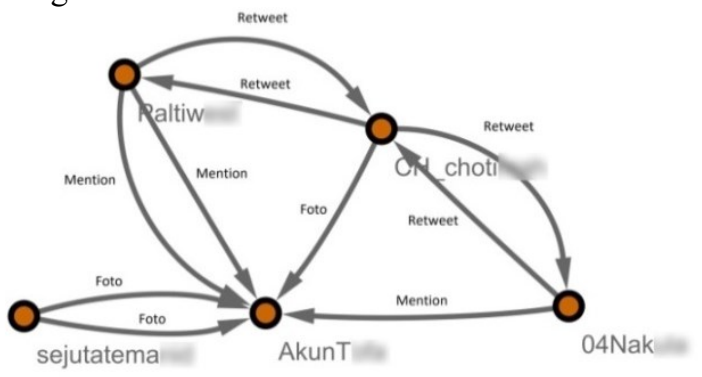

Gambar 8. Relasi Information Exchange Antar Aktor Utama

Gambar 8 merupakan visualisasi dari pertukaran informasi yang terjadi antar aktor utama tagar
\#RatnaMilikSiapa. Didalam gambar tersebut, dapat diidentifikasi aktivitas information exchange yang dibuat pada tabel 3 .

Tabel 3. Information Exchange Antar Aktor Utama

\begin{tabular}{ccc}
\hline Aktor & Reetweet & Source \\
\hline Paltiwxxx & Tweet 3 & CH_chotixxx \\
CH_chotixxx & Tweet 6 & Paltiwxxx \\
CH_chotixxx & Tweet 1 & 04nakxxx \\
04nakxxx & Tweet 3 & CH_chotixxx \\
\hline
\end{tabular}

Tabel 3 merupakan identifikasi dari pertukaran informasi yang terjadi antar aktor utama. Pada gambar 8 dan tabel 3 dapat dilihat bahwa pertukaran informasi hanya dilakukan oleh 04nakxxx, CH_chotixxx, dan Paltiwxxx dengan me-retweet postingan (tweet) dari masing-masing aktor. Di dalam tweet-tweet yang mengalami pertukaran tersebut semuanya memuat tentang tweet yang merupakan penyanggahan terhadap tagar \#RatnaMilikSiapa yang dibuat oleh AkunTxxx.

\subsubsection{Identifikasi Aktor Kunci (Key Actor)}

Key aktor adalah individu atau aktor yang berperan penting dalam penyebaran tagar \#RatnaMilikSiapa terkhusunya para aktor yang melakukan aktivitas Information Exchange. Key actor terdiri dari pembuat tagar (creator) dan penyebar informasi (influencers). Dari kelima aktor utama dan para aktor pengikut didalam jaringan masing-masing, dibuat relasi seperti pada gambar 9.

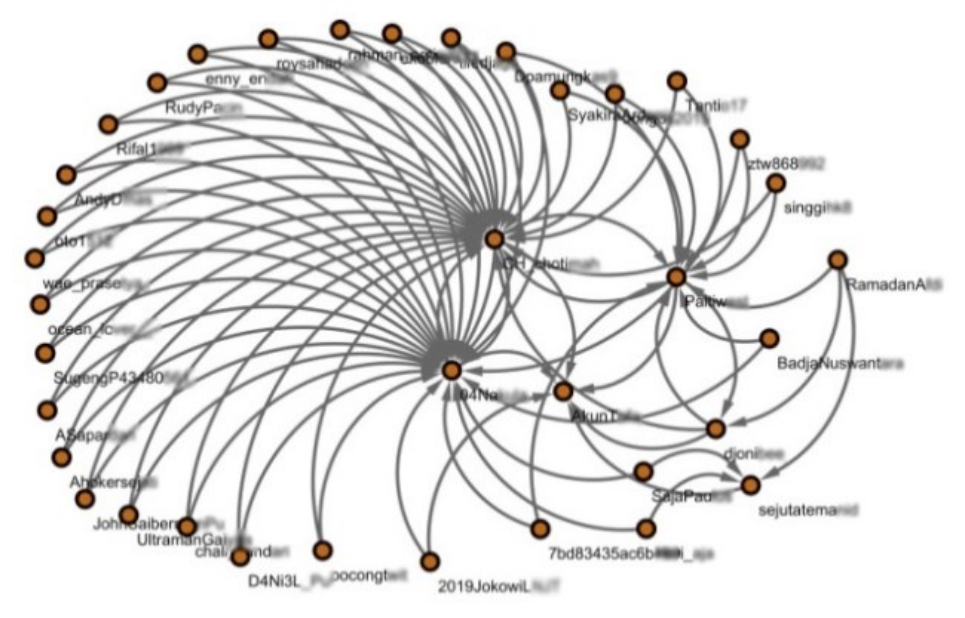

Gambar 9. Relasi Kerkaitan Aktor Utama

Gambar 9 merupakan visualissi dari hubungan antara aktor utama dengan para aktor lainnya yang saling berhubungan dengan lebih dari satu aktor utama. Key actor dapat ditentukan dengan melakukan analisis betweenness centrality (BC). Aktor dengan nilai $\mathrm{BC}$ tertinggi memiliki peran paling penting dalam sebuah jaringan karena berperan sebagai penghubung dua kelompok jaringan yang berbeda, dapat mengontrol informasi, dan juga memanipulasi informasi (Eriyanto, 2014). Analisis BC terhadap relasi pada gambar 9 dapat dilihat pada tabel 4 .

Tabel 4. Tabel Betweenness Centrality

\begin{tabular}{cc}
\hline Aktor & BC \\
\hline 04nakxxx & 0.43050265 \\
CH_chotixxx & 0.42833093 \\
Paltiwxxx & 0.0882203 \\
\hline
\end{tabular}


Tabel 4 merupakan hasil dari perhitungan BC pada hubungan keterkaitan pada gambar 9 terhadap tiga aktor utama yang melakukan aktivitas informaton exchange. Dari tabel tersebut terlihat bahwa 04nakxxx dan $\mathrm{CH}$ chotixxx memiliki nilai $\mathrm{BC}$ tertinggi. Berdasarkan tabel 4, tabel 3, dan tabel 2, jika setiap hubungan antar aktor utama dihubungkan dengan waktu dari setiap tweet yang dibuat oleh para aktor maka dapat ditentukan key actor sebagai berikut :

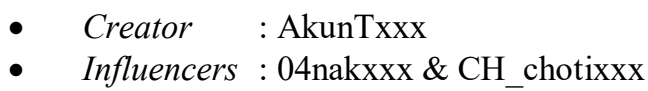

\subsubsection{Identifikasi Boundary Spanner (BS)}

Setelah dilakukan analisa terhadap aktivitas information exchange, pada gambar 9 terlihat adanya para aktor yang disebut sebagai boundary spanner. BS merupakan aktor yang melakukan komunikasi dua arah antar dua kelompok jaringan atau lebih yang diciptakan oleh para aktor utama. Berikut adalah aktor pengikut yang tegolong boundary spanner yang terdapat dalam tabel 5.

Tabel 5 merupakan aktor-aktor followers yang berhubungan dengan dua atau lebih dari satu kelompok jaringan. Pada tabel tersebut, identifikasi aktor Boundary spanner dilakukan dengan melihat interaksi langsung yang dilakukan antara aktor followers dan aktor utama. Dengan adanya BS maka dapat dilihat adanya dampak yang ditimbulkan oleh aktivitas information exchange dimana para aktor followers atau aktor-aktor pengikut yang awalnya mengikuti dan menyerap informasi dari satu aktor utama, juga melakukan hal yang sama terhadap aktor utama lainnya. Interaksi yang terjadi memperlihatkan para aktor boundary spanner hanya melakukan perpindahan relasi terhadap para aktor utama yang menyanggah \#RatnaMilikSiapa sehingga hal ini menunjukan bahwa pengguna twitter khususnya masyarakat Indonesia dalam kasus ini lebih berpihak terhadap adanya penyanggahan tweet dengan tagar \#RatnaMilikSiapa.

Kelebihan dari aktor BS adalah menghubungkan satu atau lebih jaringan dengan memperkenalkan informasi dan mendorong para aktor didalam jaringan untuk lebih memahami informasi yang berada diluar kelompok jaringannya sendiri (Committee Mb-007, 2005). Adanya hubungan dua arah yang dilakukan oleh BS dikarenakan aktivitas saling retweet yang dilakukan oleh para aktor utama dalam melakukan information exchange. Aktivitas tersebut secara otomatis akan membuat para aktor followers dari tiap-tiap kelompok jaringan dapat melihat dan menyerap informasi dari kelompok jaringan yang lain.

Dengan dihasilkannya Boundary Spanner, penelitian ini menunjukan bahwa SNA mampu memperlihatkan kekuatan aktor utama dalam menyebarkan informasi pada jejaring sosial twitter. Saling retweet dan mention yang dilakukan oleh para aktor tersebut, memberikan pengaruh dan sekaligus menunjukan adanya kecenderungan pengguna jejaring sosial twitter dalam menyerap informasi.

Tabel 5. Interaksi Boundary Spanner.

\begin{tabular}{|c|c|}
\hline Aktor Followers & Interaksi \\
\hline RamadanAxxx & sejutatemaxxx - Paltiwxxx \\
\hline Singgxxx & CH_chotixxx - Paltiwxxx \\
\hline ztw868xxx & 0"̄nakxxx - Paltiwxxx \\
\hline Tantixxx & CH_chotixxx - Paltiwxxx \\
\hline Jongos $2 \mathrm{xxx}$ & $\mathrm{CH}$ chotixxx - Paltiwxxx \\
\hline SyakiraArdxxx & $\mathrm{CH}$ chotixxx - Paltiwxxx \\
\hline Dpamungkxxx & $\begin{array}{c}\text { Paltiwxxx - 04nakxxx - } \\
\text { CH_chotixxx }\end{array}$ \\
\hline tiledjxxx & CH_chotixxx -04 nakxxx \\
\hline Ekoblorxxx & 04nakxxx-CH_chotixxx \\
\hline Rahman_setixxx & 04nakxxx - CH_chotixxx \\
\hline Roysahadxxx & 04nakxxx-CH_chotixxx \\
\hline Enny_enxxx & CH_chotixxx $-\overline{0} 4$ nakxxx \\
\hline RudyPaxxx & 04nakxxx - CH_chotixxx \\
\hline Rifal1xxx & 04nakxxx - CH_chotixxx \\
\hline AndyDxxx & $\mathrm{CH}$ _chotixxx $-\overline{0} 4$ nakxxx \\
\hline Oto1 xxx & 04nakxxx-CH_chotixxx \\
\hline Wae_prasexxx & CH_chotixxx $-\overline{0} 4$ nakxxx \\
\hline Ocean_loxxx & 04nakxxx-CH_chotixxx \\
\hline SugengP43480xxx & CH_chotixxx $-\overline{0} 4$ nakxxx \\
\hline ASaparxxx & 04nakxxx - CH_chotixxx \\
\hline Ahokersejxxx & CH_chotixxx -04 nakxxx \\
\hline JohnSibermaxxx & CH_chotixxx -04 nakxxx \\
\hline UltramanGaixxx & $\mathrm{CH}^{-}$chotixxx -04 nakxxx \\
\hline D4Ni3Lxxx & 04nakxxx - CH_chotixxx \\
\hline pocongtxxx & CH_chotixxx -04 nakxxx \\
\hline Chali_kandxxx & CH_chotixxx -04 nakxxx \\
\hline 2019JKKWLxxx & AkunTxxx - 04nakxxx \\
\hline 7bd83435ac6bxxx & Paltiwxxx - 04nakxxx \\
\hline SajaPauxxx & Sejutatemaxxx -04 nakxxx \\
\hline Heri_xxx & Sejutatemaxxx -04 nakxxx \\
\hline djonxxx & $\begin{array}{c}\text { Paltiwxxx - AkunTxxx - } \\
\text { 04nakxxx }\end{array}$ \\
\hline BadjaNuswantxxx & 04nakxxx - Paltiwxxx \\
\hline
\end{tabular}

Kecenderungan tersebut memperlihatkan apakah pengguna jejaring sosial twitter terkhususnya pengguna dengan \#RatnaMilikSiapa hanya menyerap satu informasi ataukah pengguna tersebut menyerap informasi dari beberapa sumber yang berbeda. Hal tersebut dapat dilihat dengan adanya aktor yang hanya menyerap informasi dari satu aktor utama sehingga aktor tersebut tergabung dalam satu kelompok jaringan saja dan ada juga aktor yang merespon informasi baru yang berasal dari kelompok jaringan yang lain sehingga membawanya tergabung kedalam lebih dari satu kelompok jaringan yang diciptakan oleh para aktor utama.

\subsection{Generalisasi}

Setelah dilakukan ekstraksi knowledge pada penyebaran status tweet dengan tagar \#RatnaMilikSiapa, metode ini dapat digeneralisasi terhadap kasus-kasus lain yang terdapat pada jejaring sosial twitter. Metode ini dapat diterapkan pada kasus-kasus dengan kriteria sebagai berikut : 
- Terdiri dari beberapa sumber informasi sehingga dapat terlihat adanya aktor utama penyebaran informasi.

- $\quad$ Setiap aktor utama memiliki informasi yang berbeda dengan aktor utama lainnya.

- $\quad$ Adanya pertukaran informasi antar aktor utama sehingga dapat dilihat seberapa penting peran aktor utama dan pengaruhnya terhadap penyebaran sebuah informasi dalam jaringan komunikasi.

Me-refer pada penelitian yang berjudul "Influencer Detection of Indonesia Citizens'opinion Toward Chemical Castrated Punishment for Perpetrators of Phedophile Using Social Networks Analysis" (Talakua dkk, 2018), dilakukan ekstraksi knowledge terhadap data twitter yang dipakai pada penelitian tersebut. Dengan dilakukan ekstraksi terhadap 156 relasi pada tweet yang menggunakan tagar \#KebiriKimia seperti pada Mapping SNA (1) dalam penelitan tersebut, perhitungan DC \& $\mathrm{BC}$ menghasilkan adanya aktor utama dan aktor kunci yang sama dengan hasil dari penelitian tersebut. Namun dengan metode yang digunakan pada penelitian ini, tidak ditemukan adanya aktivitas information exchange pada penelitan tersebut sehingga tidak dapat diidentifikasi peran dari para aktor utama dan pengaruhnya terhadap anggota kelompok jaringan yang ditandai dengan tidak adanya aktor boundary spanner pada penelitian tersebut.

\section{KESIMPULAN}

Kesimpulan dari penelitian ini adalah melakukan ekstraksi knowledge di dalam jejaring sosial Twitter dapat dilakukan dengan menggunakan metode Social Network Analysis (SNA) dengan melakukan perhitungan Degree Centrality (DC) dan Betweenness Centrality (BC). Analisa DC dan BC bertujuan untuk mengidentifikasi aktor-aktor utama dan seberapa penting aktor-aktor tersebut dalam penyebaran tweet yang menggunakan tagar \#RatnaMilikSiapa. Aktor-aktor tersebut berperan penting dalam menciptakan kelompok-kelompok jaringan komunikasi yang saling berketerkaitan.

Infomation Exchange (pertukaran informasi) yang dilakukan oleh para aktor utama didalam jaringan komunikasi bertujuan untuk melihat seberapa besar pengaruh terhadap para anggota jaringan atau aktor followers dari setiap jaringan yang diciptakan. Hal ini ditandai dengan adanya aktor Boundary Spanner (BS) atau aktor yang melakukan hubungan dua arah dengan lebih dari satu kelompok jaringan sehingga dapat dikatakan bahwa para aktor BS memiliki lebih dari satu informasi yang dibuat oleh para aktor utama. Metode tersebut memperlihatkan pola dari para anggota jaringan dalam menerima dan menyerap informasi yang disebarkan oleh para aktor utama penyebaran berita dengan tagar \#RatnaMilikSiapa pada jejaring sosial Twitter.

Dengan dihasilkannya para aktor utama, aktor kunci dan boundary spanner, hal ini menunjukan bahwa SNA mampu memperlihatkan kaberpihakan terhadap hoax dengan tagar \#RatnaMilikSiapa dan bagaimana para pengguna jejaring sosial twitter dalam menyerap informasi yang ada dengan langsung merespon informasi tersebut sehingga membawa aktor tersebut masuk ke dalam kelompok jaringan yang baru ataukah aktor tersebut tidak merespon sama sekali dengan kata lain hanya tergabung ke dalam satu kelompok jaringan.

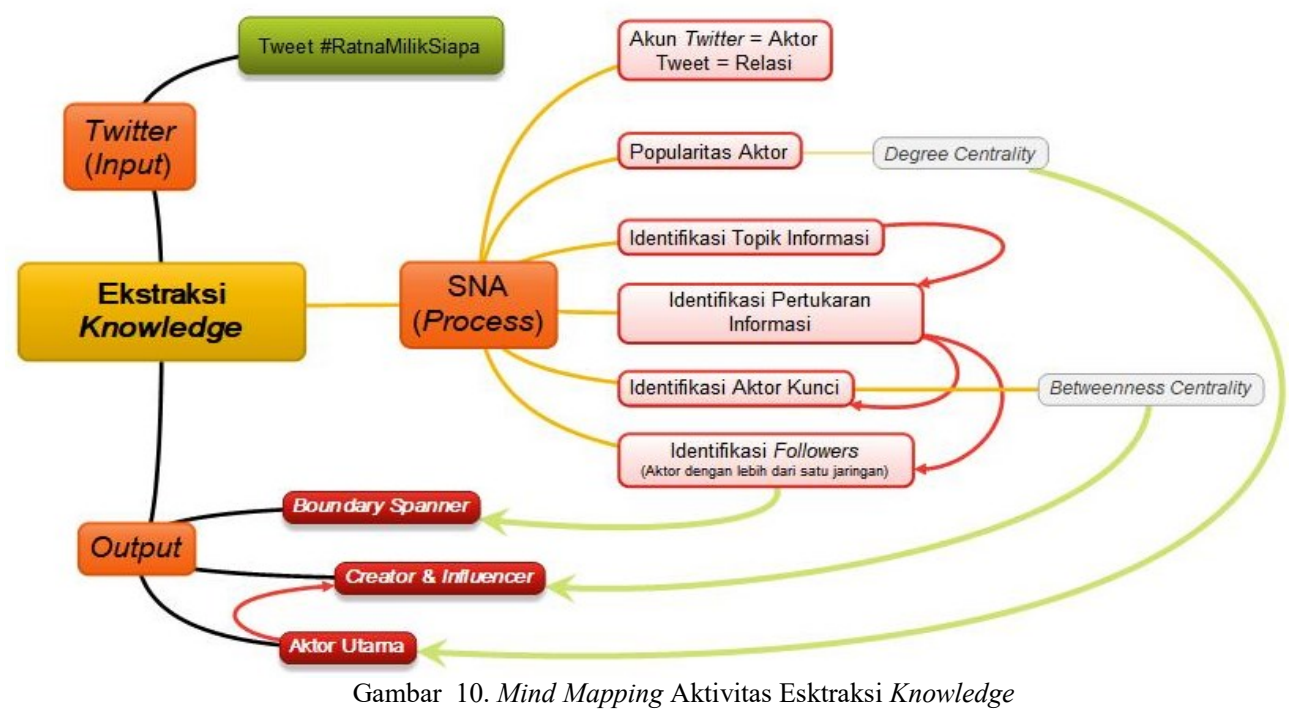

Gambar 9 merupakan keseluruhan dari aktivitas ekstraksi knowledge penyebaran \#RatnaMilikSiapa pada jejaring sosial twitter menggunakan SNA sehingga memperlihatkan adanya aktor utama, creator \& influencer, dan boundary spanner yang merupakan hasil dari ekstraksi knowledge. 


\section{DAFTAR PUSTAKA}

COMMITTEE MB-007. 2005, "Knowledge Management - A Guide". Standards Australia, Sydney, NSW 2001, Australia, ISBN 0733769306.

COSSU, J., DUGUE , N., LABATUT, V., 2015. Detecting Real-World Influence Through Twitter. Second European Network Intelligence Conference, 978-1-4673-75924/15 IEEE DOI 10.1109/ENIC.2015.20

ERDIANTO, A. 2018. Polemik Dugaan Penganiayaan RS, (Online), (https://nasional.kompas.com/read/2018/10/ 03/08490691/polemik-dugaanpenganiayaan-RS-sarumpaet?page $=$ all. Diakses 10 Nov 2018)

ERIYANTO., 2014. Analisis Jaringan Komunikasi, 1st Editio. Jakarta: Prenadamedia Group.

GRANDJEAN. M. 2016. A Social Network Analysis of Twitter: Mapping The Digital Humanities Community. Cogent Arts \& Humanities (2016), 3: 1171458

MADCOMS., 2010. Facebook, Twitter, dan Plurk dalam Satu Genggaman. Yogyakarya : ANDI.

PUDJAJANA, A.M., MANONGGA, D., IRIANI, A., PURNOMO, H.D., 2018. Identification of Influencers in Social Media Using Social Network Analysis (SNA). 2018 International Seminar on Research Of Information Technology and Intellegent System (ISRITI). STMIK AKAKOM, Yogyakarta.

SAGANOWSKI, S., 2015. Predicting Community Evolution in Social Network. International Conference on Advances in Social Networks Analysis and Mining, ACM ISBN 978-14503-3854-7/15/08,

DOI: http://dx.doi.org/10.1145/2808797.2809353

SITUNGKIR, H., 2017. Spread of hoax in Social Media A report on empirical case. Journal of Economic Perspectives-Volume 31, Number 2-Spring 2017-Pages 211-236.

RIZQO, K. 2018. RS : Kali Ini Saya Pencipta Hoax, (Online), https://news.detik.com/berita/4240438/RSsarumpaet-kali-ini-saya-pencipta-hoax. (Diakses 10 Nov 2018).

SUPRIYATNA, I. 2018. RS Disebut Penyusup, Fadli Zon : Harusnya Diselidiki, (Online), https://www.suara.com/news/2018/10/05/1 02401/RS-sarumpaet-disebut-penyusupfadli-zon-harusnya-diselidiki. (Diakses 10 Nov 2018)

TALAKUA, A., SEDIYONO, E., SEMBIRING, I., 2018. Influencer Detection of Indonesia Citizens'Opinion toward Chemical Castrated Punishment for Perpetrators of Pedophile Using Social Network Analysis, International Journal of Computer Science and Engineering (IJCSSE), Volume 7, Issue 11, Page: 264-259.

TSVETOVAT, M. \& KOUZNETSOV, A. 2011. Social Network Analysis for Startup. Sebastopol : O'Reilly Media, Inc.

WIBOWO. dan MIRAWATI., 2013. Realitas Politik Indonesia Dalam "Kacamata" Pengguna Twitter. Jurnal Kajian Komunikasi, Volume 10, No. 1, hlm 11-17.

Xianjin, Z., 1994. Research on the effective deploy of information resources in Chian, information science, 1994, 4.

YUAN. G \& JIANBIN. C., 2010. A Case Study : Social Network and Knowledge Sharing, International Conference on E-Business and E-Goverment, IEEE DOI 10.1109/ICEE.2010.434.

ZHAO, X., LIU, F., WANG, J., and LI, T., 2017. "Evaluating Influential Nodes in Social Networks by Local Centrality with A Coefficient," International Journal of GeoInformation, vol. 6, no.2, pp. 35-45. 
Halaman ini sengaja dikosongkan 